\title{
TREATMENT OF PEANUT SEEDS WITH MINT AND CLOVE ESSENTIAL OILS TO ELIMINATE FUNGAL LOAD AND AFLATOXINS PRODUCTION IN THE FINAL YIELD \\ Atwa, M.A. ${ }^{1}$; Fadia H.Ahmed ${ }^{2}$ and Neamet A.Naguib ${ }^{3}$. ${ }_{1}^{1}$ Regional Center for Food and Feed, Agric. Res. Cent. Giza \\ ${ }^{2}$ Oil CropsRes.Dept., Field crop Res, Agric. Res. Cent. Giza \\ ${ }^{3}$ Seed Tech. Res. Dept ., Field crop Res,Agric.Res. Cent. Giza
}

\begin{abstract}
This study was conducted to evaluate the antifungal effect of mint (Menthapiperita ) and clove (Syzygiumaromatic) essential oils on the fungal load, aflatoxins production and final yield of peanut crop(Arachis hypogea). Three species of peanut seed (Gregory, Giza 6 and Ismailia 1 ) were inoculated by A.flavus then treated with mint and clove essential oils (EO) and chemical antifungal vitavax to study their antifungal effect on the peanut yield after cultivation of contaminated seeds for two seasons. The yield of treatedpeanut seeds with mint and clove EOwas free from aflatoxins compared with the yield treated by chemical antifungal vitavix which gave 8ppb , 20ppb and $15 \mathrm{ppb}$ of total aflatoxins in Gregory, Giza and Ismailia 1 peanut seeds, respectively. Mint EO decreasedthe number of total fungi in first season from $15 \times 10^{4}, 29 \times 10^{4}$ and $31 \times 10^{4}$ to $7 \times 10^{2}, 8 \times 10^{3}$ and $16 \times 10^{3} \mathrm{cfu} / \mathrm{gin}$ Gregory , Giza 6 , Ismailia 1 peanut seeds, respectively .Similar result was obtained in second season .Regarding to peanut hulls, the treatment with clove EO eliminate the total fungi in contaminated peanut seed from $18 \times 10^{4}, 3.2 \times 10^{5}$ and $3.3 \times 10^{5}$ to $9 \times 10^{3}, 14 \times 10^{3}$ and $16 \times 10^{3} \mathrm{cfu} / \mathrm{g}$ in Gregory, Giza 6 and Ismailia 1, respectively in second season . No aflatoxins were detected in all samples whereasthe total fungi was ranged from $9 \times 10^{4}$ to $8.2 \times 10^{5}$ cfug. The common fungal spices were as follows: Rhizopus spp., Mucor spp., A.niger, Fusariumvericilliodis, Penicilliumaurantiogriscum, Penicilliumhirsutum, Alternaria, alternate, and Talaromycesmacrosporus. No aflatoxins were detected in all samples of peanut hulls, but it has high load of fungi which was ranged from $9 \times 10^{4}$ to $82 \times 10^{4} \mathrm{cfu} / \mathrm{g}$. Changes in Morphological traits, yield parameters and crude oil percentage were determined as agronomic characters.Results ratifies that the interaction among genotypes (Giza 6 , Ismailla 1, Gregory) and treatments (control , treatment with mint oil ,clove oil and vita ax) were significant on all estimated traits over the two seasons. Gregory with treatment (mint oil) gave the highest values of all studied characters compared to all other treatments over the two seasons followedbygenotype (Giza 6) combination with treatment with clove oil.
\end{abstract}

Keywords : Antifungal Activity, Aflatoxins, Peanut seeds, Essential oils.

\section{INTRODUCTION}

Peanut ( Arachis hypogea L.) is an important oil seed crop, and major food legume., cultivated in over 100 tropical and subtropical countries. The seed has several purposes as whole seed or processed to make peanut butter, oil soups, stews and other products. The protein, oil, fatty acid, carbohydrate and mineral content of this nut becomes sensitive to fungal contamination in pre and post- harvest stageUSDA , (1978) .

The fungal contamination is one of the main problems when inappropriate processing and storage condition occur(Asis etal., 2005).Contamination of peanut with 
mycotoxinsparticularly afatoxins, is a worldwide problem that affects both food safety and agricultural economies. Most countries have adopted regulations that limit the quantity of total aflatoxins in food and feed as 20 ppb or less; however, environmental conditions in most of the world where peanut are produced and stored often make it difficult or impossible to attain such low concentrations. In addition to aflatoxins, peanut are often contaminated with cyclopiazonic acid (CPA). Both mycotoxins are produced by Aspergillusflavus, as ubiquitous fungus that can infect and grow on peanut under both pre and post- harvest conditions(Dorner.,2008). Contamination can occur during various stages of production, harvest, handling and storage(Dieneret al.,1987). Pre-harvest aflatoxin contamination of peanuts is associated with late- season drought conditions as peanut begin to dehydrate in the soil under hot, dry environmental conditions(Cole et al ., 1989).Contamination can also occur after peanut are dug if they are not quickly harvested, dried and maintained at a safe moisture level (Bluma and Etcheverry. 2008). Aflatoxins are secondary metabolites produced by Aspergillusflavus, A. parasiticus, A. nomiusn, A. tamari and A. bombycis (Kurtzmanet al., 1987; Gotoet al., 1997 and Peterson et al., 2001). These toxins are acutely and chronically toxic to both humans and animals (Dvorackova, 1990). Among the most potent mutagenic and carcinogenic compounds known to be produced in nature, consumption of mycotoxin contaminated foods has been associated with several cases of human poisoning or mycotoxicosis, sometimes resulting in death (Abdelhamidet al.1999 and Bathnagar and Garcia,2001). Control measures to prevent fungal growth and aflatoxins production include chemical control (Bauer, 1994; Codifier et al., 1976 andHasan, 1998)., natural products and essential oils prevent much of the contamination that occur and reduced concentrations of aflatoxins in peanuts. Plants produce lots as secondary metabolites as part of their normal growth and development. One of the most important secondary metabolites are essential oils (Eos), which are extracted from plants, commonly by a distillation process (Teissedreand Waterhouse.,2000) and then used as natural additives in different foods to reduce the proliferation of microorganism and their toxins production due to their antifungal, antioxidant and anticarsionogenic properties (Bruneton,. 1995) They have received major consideration in regard to their relatively safe status and enrichment by a wide range of structurally different useful constituents(Faraget al., 1989). There have been many reports regarding the antifungal properties of plant essential oils. Some of these oils include thyme (Thymus vulgaris L.) (Thompson and Cannoin, 1986; andZambonelli et al., 1996), cinnamon(Cinnamomunzeylanicumblume), clove (Syzygiumaromaticum (L.) (Thompson and Cannion, 1986 andChatterJee, 1990); Pimenta (Capsicum anuum L.) Thompson and Cannion 1986, and basil (Ocimumbasillicum L.) (ChatterJee, 1990; andBasilico and Basilico, 1999). The extent of the inhibition of essential oils could be attributed to the presence of an aromatic nucleus containing a polar functional group being phenols, steroids and tannins. Antifungal of mint Eo is reported in other investigations( Duarte et al., 2005);Sokovic\& Van Griensven,2006,(Gulfrazet al., 2008), and Ferreira(2011). Mint oil (MenthapiperitaL.), commonly called 
peppermint is a well - known herbal remedy used for a variety of symptoms diseases. Among the indentifiedcompound some had already been reported as having antimicrobial activity, including cineole, limonene, linalool and menthol (Mazzantiet al., 1998) and(Iscanet al., 2002.). theantifungal effect of mint Eos can be attributed to menthol and 1.8- cineole which exhibited very good antifungal properties (Griffin et al., 2000). The biosynthesis of aflatoxin can be inhibited by extracts Eos from certain plants toxic to fungi and can control the fungal growth and mycotoxin production (Pinto et al.,2001),Omidbeygiet al.(2007) observed Inhibition of growth of Aspergillusflavus by using clove oil (Syzygiumaromaticum) and reported the percentage of inhibition as $87 \%$.

This study aimed to investigate the efficiency ofmint and clove essential oilsto fungal growth, aflatoxin production and seed yield of three cultivars of peanut.

\section{Essential plant oils :}

\section{MATERIALS AND METHODS}

The essential plant oils of mint (Manthapiperita) and clove (Syzygiumaromaticum) were $100 \%$ pure according to the manufactures and purchased from the Health Shop Pharmacy, Cairo, Egypt.

Artificial infection with A. flavus:

Seeds were surface disinfected for 1 min using $1 \%$ sodium hypochlorite, rinsed three times with sterile distilled water and allowed to dry. Seeds were inoculated with A. flavus(NRRL 3145,Plant Pathology Department, Agriculture Research Center).spores. A suspension of $10^{6} \mathrm{cfu} / \mathrm{ml}$ of A. flavus spores was prepared according to Davis et al., (1966). The spore suspensions were poured through muslin cloth into flasks. The seeds were added to the suspensions and mixed thoroughly. Flasks were incubation at $25^{\circ} \mathrm{C}$ for 5 days.

\section{Treatment of contaminated seeds two days before sowing}

1-The control : contaminated peanut seeds cultivars were prepared without treatment.

2-Treatment of contaminated peanut seeds cultivars with mint oil $(10 \mathrm{ml} / \mathrm{kg}$ seed)and mixed well.

3-Treatment of contaminated peanut seeds cultivars with clove oil $(10 \mathrm{ml} / \mathrm{kg}$ seed) and mixed well .

4-Treatment of contaminated peanut seeds cultivars with vitavax (200 ) 75 WP ( $3 \mathrm{~g} / \mathrm{kg}$ seed) aschemical antifungal ,commercial product.

5-After a brief drying period (5min.) , the seeds were packed into paper bags. Field trial:The contaminated cultivars Giza 6, Ismailia 1 and Gregory peanut were used in this study. The pedigree of these cultivars is shown in Table (1). Seeds were sown during the summer seasons in 2011 and 2012 at Ismailia Research Station (ARC) infection field. The treatments were arranged in split plot design with three replications in both seasons. The main plots were occupied with three contaminated cultivars and sub plothad four treatmentsEach entry was grown in a plot area of $10 \mathrm{~m} 2(4.0 \times 2.5 \mathrm{~m})$. Sowing dates were $15^{\text {th }}$ June 2011 and 2012, the cultural practices were done according to recommendations methods. The observations were 
recorded on randomly collected plants per plot for the following agronomic characters:

1. Morphological traits:Plant height $(\mathrm{cm})$, number of branches $\mathrm{pl}^{-}{ }^{-}$, number of pods pl- ${ }^{1}$ and number of seeds pl- $^{1}$

2-Yield parameters: At harvest, pods yield $\left.\mathrm{pl}^{-1} . \mathrm{g}\right)$, seed yield $\mathrm{pl}^{-}{ }^{-}$. (g), pods yield fad ${ }^{-1}$ (ard.), seed yield / fad (Kg.) and shelling \% were estimated.

3-Crude oil:Percentage was determined using soxhlet apparatus and hexane as solvent according to AO AC (2004)

Analysis of variance was calculated for each season separately according to Mather and links (1982).According to homogeneity test, the results of 2011 and 2012 did not differ significantly, so the combined analyses of the two seasons were conducted.

Table 1. Pedigree of peanut genotypes studied.

\begin{tabular}{|l|c|c|}
\hline Genotypes & Origin & Pedigree \\
\hline Giza 6 & Egypt & Commercial cultivars \\
Ismailia 1 & Egypt & Selected from Giza 4 $\times$ line 182 \\
Gregory & U.S.A & Unknown \\
\hline
\end{tabular}

Analysis of aflatoxins :

Aflatoxins were determined according to (AOAC, 2004).Weight $25 \mathrm{~g}$ test portion into blender jar. Add $5 \mathrm{~g} \mathrm{NaCl}$ and $125 \mathrm{ml}$ extraction solvent. Blend $2 \mathrm{~min}$ at high speed. Filter through prefoldedpaper. Pipt $15 \mathrm{ml}$ filtrate into $125 \mathrm{ml}$ glass-stopper Erlenmeyer flask. Add $30 \mathrm{ml} \mathrm{H}_{2} \mathrm{O}$, stopper and mix. Filter diluted extract through glass microfiber paper $\leq 30 \mathrm{~min}$ before affinity column chromatography. Pass $15 \mathrm{ml}$ filtrate through the affinity column (Vicamcompany, USA). Push distilled water through column $(10 \mathrm{ml})$. Add $1 \mathrm{ml}$ L. C grade $\mathrm{CH}_{3} \mathrm{OH}$ to elute the toxins. Collect elute and inject it through HPLC technique to determine values of Aflatoxins. HPLC system from U.S.A, Agillent company 1200), with column C18 (Lichrospher 100 RR-18), $5 \mathrm{~mm}$ $\times 25 \mathrm{~cm}$ according to the following technique: the mobile phase consisted of water: methanol: acetonitrile (54:29: $17, \mathrm{v} / \mathrm{v} / \mathrm{v})$ at flow rate $1 \mathrm{ml} / \mathrm{min}$. The excitation and emission wavelengths for all aflatoxins were 362 and 460 n.m (Florences detector), respectively (Rooset al., 1997).

Total count of fungi :

Ten grams of each sample were added to $90 \mathrm{ml}$ portion of sterile saline solution $(0.85 \% \mathrm{NaCl})$ in $500 \mathrm{ml}$ Erlenmeyers flask and homogenized thoroughly on an electric shaker, at constant speed 15 min.,ten fold serial dilutions were then prepared. One $\mathrm{ml}$ portion of suitable dilutions were used to inoculate Petri dishes containing $15 \mathrm{ml}$ Rose Bengal Agar fortified by 0.5 $\mathrm{mg}$ chloromphnicol/ml medium. Plates were counted after 3 days of incubation. The plates containing fewer than 150 colonies were retained (Paper and Fennel, 1977). 


\section{RESULTS AND DISCUSSION}

\section{A. Effect of variety and four treatmentson morphological characters of peanut}

a) Varietal differences.

Data presented in Table (2) show that the three contaminated peanut cultivars significantly differed in all traits over the two seasons, except number of pods $\mathrm{pl}^{-1}$. It is clear that $\mathrm{V}_{3}$ showed superiority in most of the studied traits. These results are in agreement with those reported by Naguibet al. (2011).

b) Treatment differences :

Data presented in Table (1)reveal that all the studied Traits were significantly affected by the four treatments. The maximum values of branch $\mathrm{pl}^{-1}$, plant height $(\mathrm{cm})$, pod length $(\mathrm{cm})$, number of pods $\mathrm{pl}^{-1}$ and number of seeds $\mathrm{pl}^{-1}$. were obtained when using $T_{2}$ followed by $T_{3}, T_{4}$ and $T_{1}$, respectively.

c) Effect of interaction :

All studied morphological characters were affected significantly by the interaction between the three studied cultivars and the four treatments (table2)

B- Effect of variety and four treatments on yield characters of peanut.

a) Varietal difference

Results in Table (3) indicated that all studied yield characters were differed over the two seasons, where $\mathrm{V}_{3}$ gave the highest pod weight $\mathrm{pl}^{-1}$ $(48.7 \mathrm{~g})$, seed weight $\mathrm{pl}^{-1}(37.0 \mathrm{~g})$, weight 100 pod(188g), weight of seed from 100 pod (123.0g), pod weight / fed (ardeb) (17.25) and oil percentage (47.3) ,except shelling \% was equal with other varieties.These results are in agreement with those reported by Naguibet al (2011).

b) Treatment differences :

Results in Table (3) indicate that all studied yield characters were significant by affected by treatment.It is clear that $\mathrm{T}_{2}$ resulted in the greatest effect on pod weight $\mathrm{pl}^{-1}(47.1 \mathrm{~g})$, seed weight $\mathrm{pl}^{-1}(36.2 \mathrm{~g})$, weight 100 pod $(197.4 \mathrm{~g})$, weight of seed from 100 pod $(133.7 \mathrm{~g})$, shelling $(68.08 \%)$, pod weight/ fed/ ardab (16.67) and oil \% (47.6)

Also, it is clear that the maximum values were obtained when using $T_{2}$ followed by $T_{3}, T_{4}$ and $T_{1}$, respectively. These results agree with those obtain byCraufurdet al. (2006) who mentioned that there were negative linear relations between aflatoxin concentration and pod yield.

C) Effect of the interactions on peanut yield and its attributes

Results in Tables, (2 and 3 ) ratify that the interactions among genotypes (Giza 6, Ismaillia 1 and Gregory) and treatments (control, treatment with mint oil, clove oil and vitavax )were significant on all estimated traits over two seasons, except shelling \%

At genotype (Gregory) in combination with the treatment (mint oil) gave the highest values of all studied characters compared to all other treatments over two seasons followed by genotype (Giza 6 ) in combination with treatment 3 (clove oil). 
Table(2):Mean Performance for some morphological characters of peanut genotypes (combined data).

\begin{tabular}{|c|c|c|c|c|c|}
\hline \multirow{2}{*}{ Characters } & \multicolumn{3}{|c|}{ Morphological characters } & \multirow{3}{*}{$\begin{array}{l}\text { No. of } \\
\text { pods } \\
/ \text { pl }^{-1}\end{array}$} & \multirow{3}{*}{$\begin{array}{c}\text { No. of } \\
\text { seeds } \\
\mathrm{pl}^{-1}\end{array}$} \\
\hline & $\begin{array}{c}\text { No. of } \\
\text { branch } \\
\text { pl }^{-1}\end{array}$ & $\begin{array}{c}\text { Plant } \\
\text { height } \\
\text { (cm) }\end{array}$ & $\begin{array}{c}\text { Pod } \\
\text { length } \\
(\mathrm{cm})\end{array}$ & & \\
\hline \multicolumn{4}{|l|}{ Treatments } & & \\
\hline \multicolumn{6}{|l|}{ Varieties (V) } \\
\hline V1 & 5.7 & 30.2 & 3.1 & 25.1 & 37.0 \\
\hline V2 & 5.6 & 33.0 & 3.5 & 26.7 & 38.7 \\
\hline V3 & 6.1 & 37.0 & 3.7 & 28.2 & 44.2 \\
\hline L.S.D at $5 \%$ & 0.2 & 1.2 & 0.2 & 4.3 & 4.9 \\
\hline \multicolumn{6}{|l|}{ Treatment } \\
\hline T1 & 5.0 & 31.4 & 3.4 & 24.5 & 37.9 \\
\hline T2 & 6.9 & 37.6 & 3.6 & 28.5 & 42.6 \\
\hline T3 & 6.0 & 34.3 & 3.4 & 27.5 & 40.3 \\
\hline T4 & 5.3 & 30.3 & 3.3 & 26.1 & 39.2 \\
\hline L.S.D at $5 \%$ & 0.3 & 1.6 & 0.2 & 2.2 & 3.7 \\
\hline \multicolumn{6}{|l|}{ interaction } \\
\hline V1T1 & 4.8 & 26.5 & 3.1 & 22.2 & 36.8 \\
\hline V1T2 & 6.6 & 36.3 & 3.2 & 27.1 & 37.6 \\
\hline V1T3 & 6.0 & 30.3 & 3.0 & 25.3 & 35.9 \\
\hline V1T4 & 5.3 & 27.5 & 3.1 & 24.9 & 37.0 \\
\hline V2T1 & 4.8 & 32.7 & 3.6 & 24.6 & 38.6 \\
\hline V2T2 & 7.0 & 37.2 & 3.7 & 28.2 & 38.7 \\
\hline V2T3 & 5.8 & 33.0 & 3.6 & 27.7 & 41.1 \\
\hline V2T4 & 4.9 & 29.1 & 3.3 & 26.9 & 35.6 \\
\hline V3T1 & 5.5 & 34.9 & 3.6 & 25.9 & 37.6 \\
\hline V3T2 & 7.1 & 39.2 & 4.1 & 30.3 & 51.8 \\
\hline V3T3 & 6.3 & 39.7 & 3.7 & 28.8 & 46.6 \\
\hline V3T4 & 5.6 & 34.4 & 3.3 & 27.2 & 41.5 \\
\hline L.S.D at $5 \%$ & 0.6 & 2.8 & 0.3 & 3.8 & 6.4 \\
\hline
\end{tabular}

It is clear that the best interaction affect was registered for the $V_{3}$ with $T_{2}$ and $V_{3}$ with $T_{3}$. Data clear that the highest values of these characters were scored by Gregory cultivar and mint oil treatments .

The effects of treatment of peanut seeds with mint and clove essential oils to eliminate fungal load and aflatoxins production in yield of first season are shown in tables 4 . The essential oils of mint and clove inhibited the growth of $A$. flavus compared with the control. The essential oils of mint and clove produced peanut yield free of aflatoxins when compared with these produced from peanut seeds without any treatments or other treated with the commercial chemical antifungal (vitavax). The essential oils of mint and clove inhibited the growth of $A$. flavus when compared with the controls. On contrast,the seeds treatment with essential oils showed the lowest levels of fungal total counts $\left(7 \times 10^{2}\right.$ for mint oil and $2.0 \times 10^{4} \mathrm{cfu} / \mathrm{g}$ for clove oil). Seeds without any treatment (control) showed the highest level oftotal fungal count $\left(3.1 \times 10^{5} \mathrm{cfu} / \mathrm{g}\right)$ in Ismailia 1 peanut seeds as shown in Tables 4 . These values ranged from $7 \times 10^{2}$ to $2.0 \times 10^{4} \mathrm{cfulg}$ in case of oils treated seeds, while it were ranged from $15 \times 10^{4} \mathrm{cfu} / \mathrm{g}$ to $3.1 \times 10^{5}$ in case of the control as seen in same Table . 
J.Agric.Chem.and Biotechn., Mansoura Univ.Vol. 5 (2), February, 2014

3 
Table (4): Effect of mint and clove essential oils on fungalload, totalaflatoxinsand isolated fungi in peanut yield of the first season:

\begin{tabular}{|c|c|c|c|c|c|c|c|c|c|}
\hline \multirow{2}{*}{\multicolumn{2}{|c|}{$\begin{array}{l}\text { Treatment } \\
\text { Peanut } \\
\text { genotypes }\end{array}$}} & \multicolumn{2}{|c|}{$\begin{array}{l}\text { Contaminated } \\
\text { seeds } \\
\text { (control) }\end{array}$} & \multicolumn{2}{|c|}{ Vitavax } & \multicolumn{2}{|c|}{ Mint oil } & \multicolumn{2}{|c|}{ Clove oil } \\
\hline & & Seeds & Hulls & Seeds & Hulls & Seeds & Hulls & Seeds & Hulls \\
\hline & T.F.C & $15 \times 10^{4}$ & $5.5 \times 10^{5}$ & $16 \times 10^{3}$ & $18 \times 10^{4}$ & $7 \times 10^{2}$ & $12 \times 10^{4}$ & $13 \times 10^{3}$ & $9 \times 10^{4}$ \\
\hline \multirow[t]{3}{*}{ Gregory } & F.I & $1,2,3$ & $3,4,5,7$ & 4,5 & 4,5 & $4,5,7$ & 4,5 & 4,5 & 4,5 \\
\hline & T.A & 22 & 0.0 & 8 & 0.0 & 0.0 & 0.0 & 0.0 & 0.0 \\
\hline & T.F.C & $2.9 \times 10^{5}$ & $8.2 \times 10^{5}$ & $2.2 \times 10^{4}$ & $2.0 \times 10^{5}$ & $8 \times 10^{3}$ & $3.5 \times 10^{5}$ & $16 \times 10^{3}$ & $12 \times 10^{4}$ \\
\hline \multirow[t]{3}{*}{ Giza 6} & F.I & $1,2,3$ & $3,4,7,8$ & 4,5 & $2,4,5$ & 4,5 & $2,3,4,5,8$ & 4,5 & $4,5,7$ \\
\hline & T.A & 3 & 0.0 & 20 & 0.0 & 0.0 & 0.0 & 0.0 & 0.0 \\
\hline & T.F.C & $3.1 \times 10^{5}$ & $3.4 \times 10^{5}$ & $2.3 \times 10^{4}$ & $3.4 \times 10$ & $16 \times 10^{3}$ & $4.3 \times 10^{5}$ & $2.0 \times 10^{4}$ & $5.7 \times 10^{5}$ \\
\hline \multirow[t]{2}{*}{ Ismailia1 } & F.I & $1,2,3$ & $3,4,8,9$ & 4,5 & $2,4,5$ & 3,6 & $4,5,6$ & 4,5 & 4,5 \\
\hline & T.A & 25 & 0.0 & 15 & 0.0 & 0.0 & 0.0 & 0.0 & 0.0 \\
\hline
\end{tabular}

T.F.C: Fungi Total count (cfu/g), F.l": Fungal isolates. T.A "': Total aflatoxins (ppb). 1= Aspergillusflavus. , 2= Aspergillusniger, 3= Fusariumverricillidis., 4= Rhizopus spp., 5= Mucor spp. 6= Talaromycesmacrosporus. $7=$ PEnicilliumaurantiogriscum. 8-Penicillium hirsutum. $9=$ Alternaria alternate.

The yield of peanut seeds treated with mint and clove essential oils showed high activity against aflatoxins production, where seeds were free of aflatoxins, while level of total aflatoxins were $8 \mathrm{ppb}, 20 \mathrm{ppb}$ and $15 \mathrm{ppb}$ in case of yields produced by treated seeds with chemical antifungal product (vitavax) in the three investigated varieties (Gregory, Giza 6, and Ismailia, respectively). High levels of total aflatoxins were found in case of seeds without any treatment (control), it reached to $22 \mathrm{ppb}, 37 \mathrm{ppb}$, and $25 \mathrm{ppb}$ in Gregory, Giza6 and Ismailia 1, respectively .

The given data showed that the fungal load of peanut hulls was higher than that of peanut seeds. It was ranged from $9 \times 10^{4} \mathrm{cfu} / \mathrm{g}$ in treated hulls with clove oil in Gregorytypeto $8.2 \times 10^{5} \mathrm{cfu} / \mathrm{g}$ for control.On the other hand, all samples of peanut hulls were free of aflatoxins,Contrary to abdelhamid (1990) who found that contained (20 folds) than peanut seeds of the same naturally infectedpods .

Data in Table (5) cleared that mint and clove Eos. Were very closed in the effect of decreasing the total fungal counts in treated peanut seeds ,where the highestnumber of total fungal counts was $3.3 \times 15^{5} \mathrm{cfu} / \mathrm{g}$ in control peanut seeds(Giza 6 ) and $3 \times 10^{4} \mathrm{cfu} / \mathrm{g}$ in treated peanut seeds with Vitavix, whereas total fungal counts of treated peanut seedswith mint and clove EOs. Were $9 \times 10^{3}$ (clove EO.) and $11 \times 10^{3} \mathrm{cfu} / \mathrm{g}$ (mint EO. ).All treated peanut seeds with Eos were free from aflatoxins. Rhizopus spp. ,Mucor spp. And were the most predominant fungal isolates from all treated peanut seeds and hulls ( Vitavix and Eos. ), also A. flavus, A. niger and F. verricillidis disappeared in vitavix,mint and clove oils in the yield of second season. It was also noted that the variety of peanut Gregory had a lower incidence of fungi than the other varieties. 
Table (5): Effect of mint and clove essential oils on fungal load,total aflatoxinsand isolated fungi in peanut yield of the second season:

\begin{tabular}{|c|c|c|c|c|c|c|c|c|c|}
\hline \multirow{2}{*}{\multicolumn{2}{|c|}{$\begin{array}{l}\text { Treatment } \\
\text { Peanut } \\
\text { genotypes }\end{array}$}} & \multicolumn{2}{|c|}{$\begin{array}{l}\text { Contaminated } \\
\text { seeds (control) }\end{array}$} & \multicolumn{2}{|c|}{ Vitavax } & \multicolumn{2}{|c|}{ Mint oil } & \multicolumn{2}{|c|}{ Clove oil } \\
\hline & & Seeds & Hulls & Seeds & Hulls & Seeds & tulls & Seeds & Hulls \\
\hline & T.F.C & $18 \times 10^{4}$ & $4.4 \times 10^{4}$ & $2.6 \times 10^{4}$ & $2.2 \times 10^{5}$ & $11 \times 10^{3}$ & $16 \times 10^{4}$ & $9 \times 10^{3}$ & $13 \times 10^{4}$ \\
\hline \multirow[t]{3}{*}{ Gregory } & F.I' & $1,2,3$ & $3,4,7,8$ & 4,5 & $2,4,5$ & $2,5,7$ & 4,5 & 45 & 4,5 \\
\hline & T.A & & & & & & & & \\
\hline & T.F.C & $3.2 \times 10^{5}$ & $7.6\rangle$ & $2.4 \times 10^{4}$ & $3.1 \times 10^{4}$ & $15 \times 10^{3}$ & $3.1 \times 10^{5}$ & $14 \times 10^{3}$ & $16 \times 10$ \\
\hline \multirow[t]{3}{*}{ Giza 6} & F.I & $1,2,3$ & $3,4,6,7,8$ & 4,5 & $2,4,5$ & 4,5 & 4,5 & 4,5 & 4,5 \\
\hline & T.A & 40 & 0.0 & 15 & 0.0 & 0.0 & 0.0 & 0.0 & 0.0 \\
\hline & T.F.C & $3.3 \times 10^{5}$ & $3.7 \times 10^{5}$ & $3.0 \times 10^{4}$ & $3.0 \times 10^{5}$ & $14 \times 10^{3}$ & $3.8 \times 10^{5}$ & $16 \times 10^{3}$ & $4.4 \times 10^{5}$ \\
\hline \multirow[t]{2}{*}{ Ismailia1 } & F.I & $1,2,3$ & 3,4 & 4,5 & & $4,5,6$ & 4,5 & 4,5 & 4,5 \\
\hline & T.A & 35 & 0.0 & 19 & 0.0 & 0.0 & 0.0 & 0.0 & 0.0 \\
\hline
\end{tabular}

F.T.C :Total Fungi count (cfu/g), I.F": Fungalisolates., T.A "': Total aflatoxins (ppb).

1= Aspergillusflavus. , 2= Aspergillusniger, 3= Fusariumverricillidis., 4= Rhizopus spp., 5= Mucor spp. 6= Talaromycesmacrosporus. $\quad 7=$ PEnicilliumaurantiogriscum. 8-Penicillium hirsutum. $9=$ Alternaria alternate.

The present results are correlating with Montes- Belmont and Carvajal, (1998)who reported that essential oils of peppermint (Menthapiperita) and clove (syzygiumaromaticum) caused a total inhibition of A. flavus on maize kernels. Antifungal properties of mint and clove oils on cowpea seeds have alos been recorded by Kritzinger et al., (2002). The hydrosols of anise, cumin, fennel, mint, picking herb and thym showed a strong inhibitory effect on mycelial growth of $A$. parasiticus NRRL 2999, Ozcan,(2005).Aqil et al .,(2000) observed that mint and clove essential oils can be exploited as antifungal agent in the management of plant infectious diseases and post-harvest spoilage of crops. Pundir and Jain .,(2010)reported that extract of clove was found to be highly active against A.flavus and this activity may be due to the presence of genol and caryophyllene.Roquia El-Habib, (2012)showed that essential oil of dill, coriander, basil, rosmar, mint and thym have antifungal activities against $A$. flavus and aflatoxin production in vitro. Several authors have attributed the antifungal activity of essential oils to the presence of phenolic compounds and the amphipathicity of these compounds can explain their interactions with biomembrane and thus the antimicrobial activity (Veldhuizenet al., 2006).

Ultee et al .,(2002) suggested that , the main charractesistics of essential oils is theirhydrophobiacity, which enables their incorporation into the cell membrane This activity may be due to the presence of phenolic monoterpene which has a hydroxyl group around the phenolic ring and exhibits into antifungal activity through the disruption of the cytoplasmic membrane .

Cristaniet al., (2007), indicated that the hydrophilic part of the molecule interacts with the polar part of the membrane, while the hydrophobic benzene ring and the aliphatic side chains are in the hydrophobic inner part at the bacterial membrane, furthermore, the involvement of the hydroxyl group in the formation of hydrogen bonds and the acidity of these phenolic 
compounds may have other possible explanations. Dafereraet al., (2000), suggested that the fungitoxic activity of the essential oils may have been due to formation of hydrogen bonds between the hydroxyl group of oil phenolics and active sites of target enzymes. Lucini et al., (2006) indicated that mycelial growth inhibition is caused by the monoterpenes present in essential oils. These components would increase the concentration of lipidic peroxides such as hydroxyl, alkoxyl and alkoperoxyl radicals and so bring about cell death.

\section{REFERENCES}

Abdelhamid, A.M. (1990) - Occerrence of same mycotoxins (Aflatoxins,Ochratoxin-A, citrinine ,zearalenone and vomitoxin) in various Egyptian feeds. Arch .Nutr. , Berlin ,40=647-664.

Abdelhamid ,A.M.i El - mansoury , A.M.iOsaman, A.I - and El - Azab , S.M. (1999).Mycotoxins as causative for human food poisoning under Egyptian conditions .J .Agric.Sci Mansoura univ., 24 : 2751 - 2757.

AOAC (2004). Association of Official Analytical Chemists, Official Method of Analysis, $26^{\text {th }}$ edition, Benjamin Franklin Station.

Aqil F., Beng AZ, Ahmad I. (2000):In vitro toxicity f plant essential oils gainst soil fungi. J. Med., ARom Pi. Sci. 23: 177-181.

Asis R., Barronuevo D.L, Giorda L.M., Nores M.L.and Aldao M.A. (2005).Aflatoxin production in six peanut (Arachis hypogea L.) genotypes infected with Aspersillusflavusand Aspersillusparasiticus, isolated from peanut production areas of cordoba, Argentina. J. Agric. Food Chem. 53 : 9274-9280.

Basilico, M.Z. and Basilico, J.C. (1999). Inhibitory effects of some spice essential oils on Aspergillusochraceus NRRL 3174 growth and ochratoxinA production. Litters in Applied Microbiology, 29, 238-241.

Bathnagar, D. and Garcia, S. (2001).Aspergillus. In Labbe, R.G. and Garcia, S. (eds.). Guide to Foodborne Pathogens. JohnWiley and Sons, New York, pp. 35-49.

Bauer,J.(1994).MoglichkeitenzurEntgiftungmykotoxinhaltigerFuttermittel.Monat sherifte fur Veterinamedizin, 49: 175-181.

Bluma, R.V. andEtcheverry , M.G. (2008). Application of essential oils in maiza grain: Impact on Aspergillus section flavi growth parameters and aflatoxin accumulation. Food Microbiology, 25 (2); 324-334.

Bruneton, J. (1995).Pharmacognosy photochemistry of Medicinal plant. Andover, UK: Intercept LimiteAnodover. UK.

Chatterjee, D. (1990).Inhibition of fungal growth and infection in maize grains by spice oils. Letters in Applied Microbiology, 11;148-151.

Codifier, L.P., Mann, G.E. and Dollear, F.G. (1976).Aflatoxin inactivation: Treatmet of peanut meal with formaldehyde and calcium hydroxide, Journal of the American Oil Chemists Society, 53, 204-206.

Cole RJ, Sanders TH, Dorner JW andBlankn Ship PD.(1989).Environmental condition required to induce preharvestaflatoxin contamination of groundnuts summary of six years research. In:Hall SD, editor Aflatoxin contamination of groundnut procedings of international work shop, 6-9 October 1987. Patanchery AP, India .ICRISAT center pp 279-287. 
Craufurd, P.Q ; Prasad , P. V.V. ; Waliyar, F and Tahen, A (2006). Drought, pod yield, pre harvest Aspergillus infection and aflatoxin contamination on peanut in viger field Crops Research ,(98), (1):20-29.

Cristani, M., d'Arrigo, M., Mandalari, G., Castelli, F., Sarpietro, M. G., Micieli, D., Venuti, V., Bisignano, G.; Saija, A. and Trombetta, D. (2007). Interaction of four monoterpenes contained in essential oils with model membranes: Implications for their antibacterial activity. Journal of Agricultural and Food Chemistry, 55(15): 6300-6308.

Daferera, D.J., Ziogas, B.N. and Polissiou, M.G. (2000).GC-MS analysis of essential oils from some Greek aromatic plants and their fungitoxicity on Penicilliumdigitatum. Journal Agricultural and Food Chemistry 48: 2576-2581.

Davis, N.D.; DionerU.L. and El-DridyeD.W.(1966). Production of aflatoxins B1 and $\mathrm{G} 1$ by Aspergillusflavus in a semisynthetic medium.ApplMicrobiol, 14: 378-380.

Diener U.L, Cole RJ , Sanders TH, Payme GA and, Leels, Kkich MA. (1987). Epidemiology of aflatoxin formation by Aspersillusflavus Annual Review of Phyropathology, 25: 249- 270

Dorner. J. W(2008).Management and prevention of mycotoxins in peanuts. Food Additives andContaminants, February 25 (2) ; 203-208

Duarte MCT, Figueira GM, Satoratt A, Rehder VLG,andDelamelina CN (2005).Anti- Candida of Brazillan medicinal plant. J. Ethnopharmacol 97:305-311.

Dvorackova, I. (1990).AFlatoxins and Human Health. CRC Press, Inc., Boca Raton, Fla.

Farag, R.S., Daw, Z.Y, and Abo- Raya, S.H. (1989).Influence of some spice essential oils on Aspergillusparasiticus growth and production of aflatoxins in asynthetic medium Journal of Food Science, 54 (1),74- 76.

Ferreira, D.F. (2011).Analisesestatisticaspormpio do sisvar para windows versao 4.0.In 45 a ReuniaoAnual da RegiaoBrasiliradarsociedadeinterncional de Biometra.Ufscar, saocarlos, Sp, Jutho de 2000. p. 255-258. Disponivelem.

Goto, T., Ito, Y., Peterson, S.W. and Wicklow, D.T (1997).Mycotoxin production ability of Aspergillus tamari, Mycotoxins, 44, 17-20.

Griffin GS, Mar Kham W, Leach ND (2000).Amagar dilution method for the determination of the minimun inhibitory concentration of essential oils $\mathrm{J}$ EssentOil Res 12: 149 - 255.

Gulfraz M, Mehmood S, Minhas N, Jabeen N, Kausar R, JabeenK, and Arshad G (2008).Composition and antimicrobial properties of essential oil of Foniculumvulgare.Afri. J. Biotecha 24: 4364- 4368.

Hasan, H.A.H. (1998).Studies on toxigenic fungi in roasted foodstuff (salted seed) and halotolerant activity of emodin-producing Aspergilluswentii. Folia Microbiologica, 43: 383-391.

Iscan, G., Kirimer, N., Kurcuoglu, M., Baser, K.H., Demirci, F. (2002).Antibacterial screening of Methapiperta essential oils. Journal of Agricultural and Food Chemistry 50, 3943 - 3946. 
Kritzinger.Q,T.A.S. Avelingand W.F.O. Marasas ,( 2002). Effect of essential plant oils on storage fungi, germination and emergence of cowpea seeds . Seed Sci. and Technol ., 30: 609-619.

Kurtzman, C.P., Horn, B.W. and HEsseltine, C.W (1987).Aspergillusnomus, a new aflatoxin producing species related to Aspergillusflavus and Aspergillus tamari.Antonie van Leeuwenhoek, 53: 147-158.

Lucini, E.I., Zunino, M.P., Lopez, M.L. and Zygadlo, J.A. (2006).Effect of monoterpenes on lipid composition and sclerotial development of SclerotiumcepivorumBerk. Journal of Phytopathology, 154: 441-446.

Mather, K. and linksJ.L. (1982).Biometrical Genetics. ( $3^{\text {rd }}$ Edition) Champman and Hall, London.

Mazzanti, G., Battinelli, L. and Salvatore, G.(1998). Antimicrobial properties of the linalool - vrch essential oil of Hyssopus of Ficinalis L. var. decumbens (Lamiaceae). Flavor and Fragrance Journal 13: 289-294.

Montes-Belmont, R. and Carvajal, M. (1998). Control of Aspergillusflavus in maize with plant essential oils and their componers, J. of Food Protection, 61(5)616 - 624 .

Naguib,N. A. ,Abd- ElaalA.V.A and El ShakhessSamar, A.M. (2011).Variability, Seed testing, genetic parameters, chemical composition and protein banding of ten peanut genotypes. Egypt. J. Plant Breed. , 15 (5): 187-212 (2011).

Omidbeygi, M., M. Barzegr, Z. Hamidi and H. Naghdibadi (2007). Antifungal activity of thyme, summers savory and clove essential oil against Asprgillus, flavas in liquid mediam and tomato paste. Food Control, 18: 1518-1523.

Ozcan, M. (2005).Effect of spice hydrosols on the growth of Aspergillusparasiticus NRRL 2999 strain. Journal of Medicine Food, 8(2): 275-278.

Paper, K.P. and Fennel, D.I. (1977). The genus Aspergillus .R.E. Krieger Publishing Company, Unitngton, New York.

Peterson, S.W., Ito, Y., Horn, B.W. and Goto, T. (2001).Aseprgillusbombycis, a new aflatoxingenic species and genetic variation in its sibling species, A. nomius.Mycologia, 93(4), 689-703.

Pinto, M. M., GonealesE.,RossiM. H., FelicioJ. D., MedinaC.S, Fevnandes aM. J. B. and SimoniL.C.(2001) . Activity of the aqueous extract from polymniasoncnifolia leaves on growth and production of aflatoxin B by Aspergillus. Flavus. Braz. J. Microbiol .;32: 127-129

Punder. R.K. and Jain P. (2010): Antifungal activity of twenty two ethanolicplant extracts against food-assocuated fungi. J. ofPharamacy Res., 3(1): 506-510.

Roos, A.H., KampH.J Van der, and MarleyE.C. (1997). Comparison of immunoaffinity columns for the determination of aflatoxins in animal

feed and maize. Mycotoxin Research, 13: 1-10.

Roquia El-Habib (2012).Antifungal activity of some essential oils on Aspergillusflavus growth and aflatoxin production. Journal of Food Agriculture and Environment,. 10(2): 274-279. 
Sokovic M. and Van Griensven ULD (2006).Antimicrobia activity of essential oils and their components against tle three major pathogens of cultivated bulton mushroom, Agaricusbisporus. Eur J Plant Pathol 116: 211-224.

Teissedre, P.L., Waterhouse, A. L. (2000). Inhibition of oxidantion of Human Low Density Lipoprotpins by phenolic substances in Different Essential oils varieties - Journal of Agricultural and Food Chemistry , 48 (9), 3801 $-3805$.

Thompson, D.P. and Cannoin, C. (1986).Toxicity of essential oils on toxigenic and nontoxigenic fungi. Bulletin of Environ. Contam .Toxicol , 36: 527532.

Veldhuizen, E.J., Tjeerdsma-vanBokhoven, J.L. Zweijtzer, C., Burt, S.A. and Haagsman, H.P. (2006).Structural requirements for the antimicrobial activity of carvacrol. Journal of Agricultural and Food Chemistry 54: 1874-1879.

Ultee .A , M . H .J .Bemnik and R .moezear ,( 2002). the phenolic hydroxyl group of carvacrol is essential fer action against the food - borne pathogen bacillus cereus . applied and environmental microbiology, vol . 68 , No. 4 , pp. $1561-1568$.

USDA , (1978) . united states department of agriculture . agriculture statistics . Washington, D.C.

Zambonelli, A.,IZechiniD'Aulerio, A., Bianchi, A. and Albasini, A. (1996).Effects of essential oils on phytophathogenic fungi in vitro. Journal of Phytopathology, 144, 491-494.

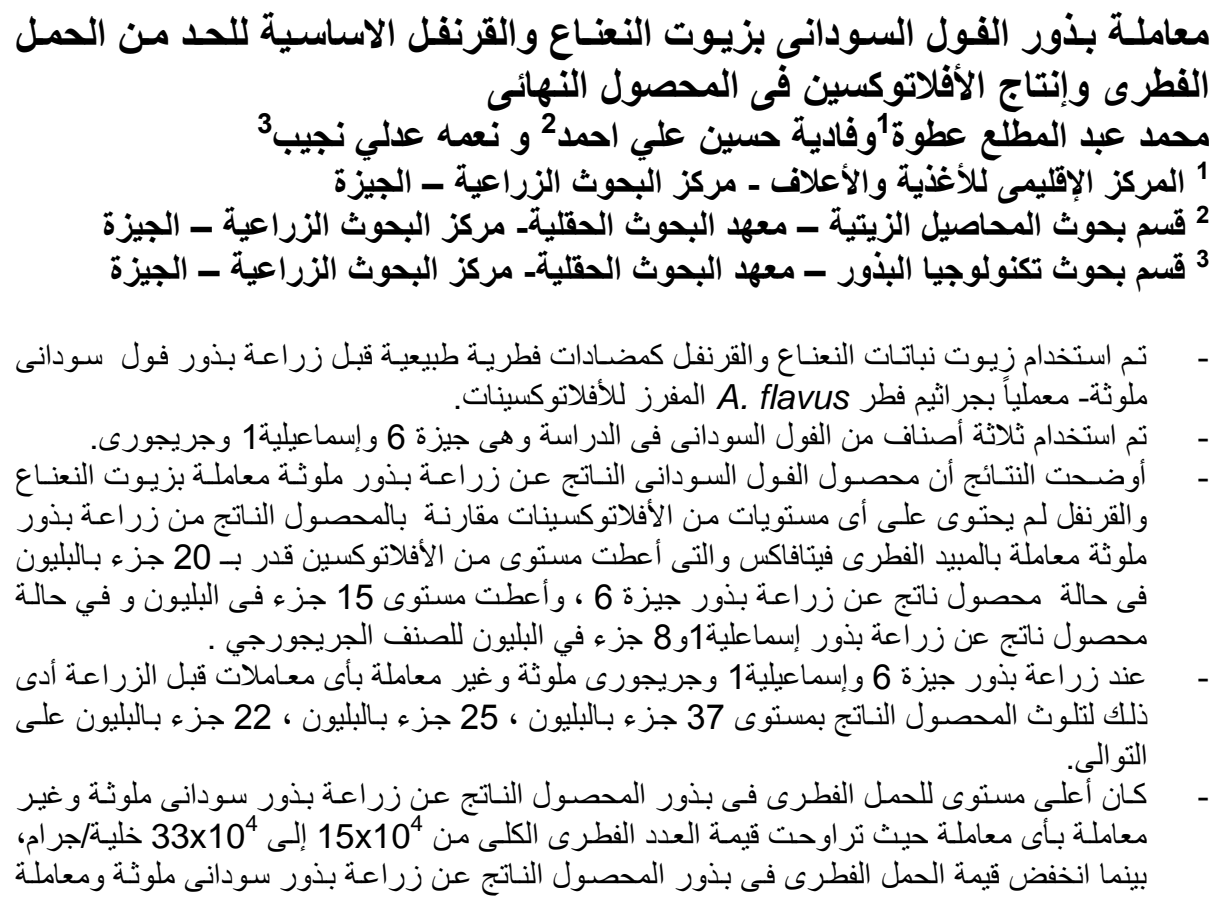




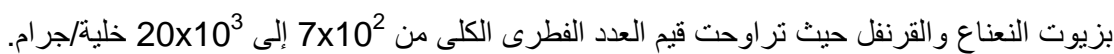
أوضحت النتائج نو اجد فطر A. flavus فى بذور المحصول الناتج من زر اعة بذور ملوثئة وغير معاملة بأى معاملات

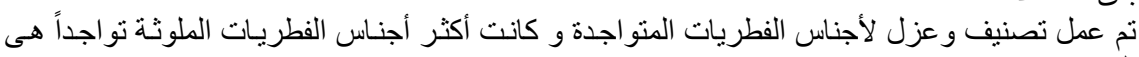
Fusariumverricilliodis, 'A.niger ، Mucor spp. ، Rhizopusspp. Penicilliumaurantiogriscum, hirsutum, Alternaria alter
Talaromycesmacrosporus.

كانت عينات قثور الفول السودانى كانت خالية من الأفلاتوكسينات ولكنها كانت ذات حمل فطرى عالى

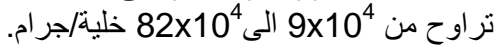

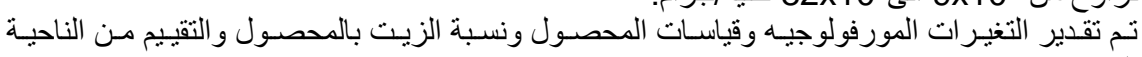
الزراعيه.

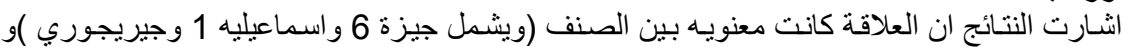

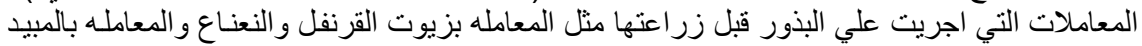

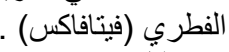
تم تحليل عينات محصول الفئل الفول السوداني الناتج من زر اعة البذور المعامله وذلك خـلال موسمين زر اعهـ منتاليان.

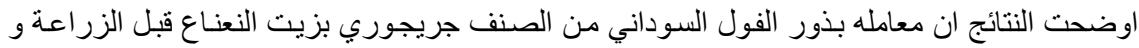

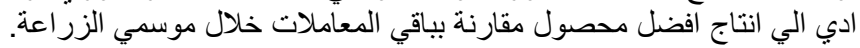

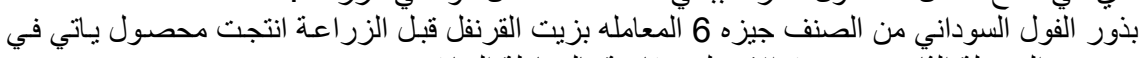
المرحلة الثانيه من حيث الافضليه مقارنة بالمعاملة السابقه.

كلية الزراعة - جامعة المنصورة

كلية الزراعة - جامعة عين شمس
قام بتحكيم البحث

أ.د / عبد الحميد محمد عبد الحميد

أ.د ا رمضان ثابت عبد ربة 
J.Agric.Chem.and Biotechn., Mansoura Univ.Vol. 5 (2), February, 2014 

Table (3): Performance of pods yield, seeds yield and shelling for peanut genotypes (combined data)

\begin{tabular}{|c|c|c|c|c|c|c|c|c|c|}
\hline Characters & $\begin{array}{c}\text { Pod } \\
\text { wiegh pl } \\
1 / g\end{array}$ & $\begin{array}{c}\text { Seed } \\
\text { weight pl } \\
1 / g\end{array}$ & $\begin{array}{l}\text { Weight } \\
100 \\
\operatorname{pod} / g\end{array}$ & $\begin{array}{c}\text { Weight of } \\
\text { seeds from } \\
100 \text { pod/g }\end{array}$ & Shelling \% & $\begin{array}{c}\text { Pod } \\
\text { weight } \\
\text { /fed } \\
\text { (Ardeb) }\end{array}$ & $\begin{array}{c}\text { Seed } \\
\text { Weight } \\
\text { /fed } \\
\text { (ardab) }\end{array}$ & $\begin{array}{c}\text { Seed } \\
\text { Weight } \\
/ \text { fed /kg }\end{array}$ & Oil \% \\
\hline \multicolumn{10}{|l|}{ Varieties (V) } \\
\hline V1 & 41.5 & 30.6 & 172.6 & 114.0 & 65.84 & 14.21 & 12.92 & 990.9 & 44.6 \\
\hline V2 & 43.4 & 32.5 & 180.0 & 118.0 & 65.61 & 15.17 & 13.71 & 949.0 & 46.7 \\
\hline V3 & 48.7 & 37.0 & 188.0 & 123.0 & 65.63 & 17.25 & 15.63 & 1199.0 & 47.3 \\
\hline L.S.D at $5 \%$ & 3.1 & 2.1 & 6.5 & 4.6 & 2.27 & 1.45 & 0.88 & 201.6 & 1.4 \\
\hline \multicolumn{10}{|l|}{ Treatment } \\
\hline T1 & 41.8 & 30.4 & 163.3 & 104.0 & 63.71 & 14.39 & 12.83 & 985.4 & 45.9 \\
\hline T2 & 47.1 & 36.2 & 197.4 & 133.7 & 68.08 & 16.67 & 15.33 & 1036.0 & 47.6 \\
\hline T3 & 45.1 & 33.9 & 185.5 & 121.2 & 65.42 & 15.72 & 14.17 & 1097.0 & 46.2 \\
\hline T4 & 44.2 & 32.9 & 174.6 & 114.4 & 65.57 & 15.39 & 14.00 & 1067.0 & 45.3 \\
\hline L.S.D at $5 \%$ & 2.7 & 2.0 & 6.3 & 4.9 & 3.63 & 1.14 & 0.86 & 204.2 & 1.5 \\
\hline \multicolumn{10}{|l|}{ interaction } \\
\hline V1T1 & 39.6 & 29.5 & 151.0 & 93.64 & 62.02 & 13.50 & 12.50 & 961.7 & 43.3 \\
\hline V1T2 & 42.8 & 31.7 & 186.2 & 133.1 & 71.49 & 14.83 & 13.33 & 1028.0 & 46.5 \\
\hline V1T3 & 41.5 & 30.8 & 179.5 & 117.1 & 65.21 & 14.17 & 12.83 & 991.8 & 44.3 \\
\hline V1T4 & 40.8 & 30.1 & 173.9 & 112.3 & 64.64 & 14.33 & 13.00 & 982.1 & 44.4 \\
\hline V2T1 & 40.6 & 30.6 & 165.8 & 108.6 & 65.53 & 14.00 & 13.00 & 995.6 & 45.6 \\
\hline V2T2 & 45.3 & 34.8 & 196.7 & 129.9 & 66.30 & 16.00 & 14.67 & 715.2 & 47.9 \\
\hline V2T3 & 43.8 & 32.2 & 183.1 & 119.7 & 65.42 & 15.33 & 13.50 & 1049.0 & 47.8 \\
\hline V2T4 & 43.6 & 31.9 & 174.4 & 113.7 & 65.21 & 15.33 & 13.67 & 1036.0 & 45.6 \\
\hline V3T1 & 44.9 & 31.1 & 173.2 & 109.8 & 63.59 & 15.67 & 13.00 & 998.8 & 48.6 \\
\hline V3T2 & 53.2 & 42.1 & 209.3 & 138.2 & 66.45 & 19.17 & 18.00 & 1366.0 & 48.3 \\
\hline V3T3 & 49.7 & 38.4 & 194.0 & 126.8 & 65.62 & 17.67 & 16.17 & 1249.0 & 46.6 \\
\hline V3T4 & 46.8 & 36.5 & 175.4 & 117.2 & 66.87 & 16.50 & 15.33 & 1182.0 & 45.8 \\
\hline L.S.D at $5 \%$ & 4.7 & 3.5 & 10.84 & 8.63 & 6.29 & 1.97 & 1.48 & 353.7 & 2.5 \\
\hline
\end{tabular}

